\title{
VENTANA DE ENFERMO
}

Recostado en la almohada, lejos de la oficina, con las puertas cerradas al trajín de mi puesto, en pocos días he visto que, en mis altas funciones, no dispongo de mí más que estando indispuesto.

He venido a ser libre entre cuatro paredes... Aquí puedo pensar: me siento desahogado. Por los aleros, sobre los bambús, entre nubes altísimas, miro el Tai Po nevado.

¡Qué nubes! Me avergüenzan: libres, sin ambiciones. Ni trepan ni se afanan en sus altas funciones.

\section{EXTRAÑO SENTIMIENTO}

Hoy me tocó velar en el palacio, Estoy aquí, sentado, como esperando el día. Y de pronto suspiro, hondamente, despacio. Nadie lo entendería,

\section{EL INSENSATO}

No hay hombre sin locura, y la mía es hacer versos. Alejado de todo, mi enfermedad me sigue. ¿Por qué un espléndido paisaje, o unos ojos amigos, me desatan como si me cruzara con Dios en este mundo? 
Y hago versos y así pierdo la vida desterrado en Sun Yan.

A veces, cuando acabo un poema, subo, loco, corriendo, al Peñón del Oriente y lo digo en voz alta frente a la inmensidad. En la quietud, los pájaros se desconciertan y los montes se extrañan y los monos me espían.

Soy un escándalo de la naturaleza, y de mí mismo, y de los míos.

\section{JIRA DE TRABAJO}

Flores sin flores, neblina sin neblina.

Oscuridad donde nada se salva.

Primavera soñada, matutina.

Llegar a media noche, partir antes del alba.

\section{AMOR DISTANTE}

Quiero olvidar, pero es en vano.

Quisiera ir, pero no puedo.

No tengo alas en los hombros.

Ya tengo blanco el pelo.

Me siento a ver caer las hojas.

Subo a la torre: el campo inmenso.

Crecen las sombras del crepúsculo.

Algo me va dejando ciego. 